\title{
Making the sale
}

\author{
Give 'em the easy choice.
}

\section{Fredric Heeren}

It was that Presbyterian biologist who almost blew the sale. And not only a sale to the Presbyterians, but to the Seventh-Day Adventists, too. Those two denominations alone could deliver 18 million customers, guaranteed. It was a good thing I came along with the sales staff for this one. Halfway through my product-design talk, the biologist interrupted, as though suddenly possessed, and began telling the others they were making a big mistake.

I brought the denominational leaders back to the purpose of the meeting when I showed them what our Personal Advice Device could do.

Of course James had done his usual great job of setting the hook. Nobody could argue with his facts. People have come to trust their PADs implicitly. More than their spouses. More than their pastors. What human being can compete with this advice from a mind programmed to think according to our individual tastes, but immeasurably smarter, continuously updated from a world of information according to our present needs?

So here's how I explained why our product is the solution to their evolution issue - and if you pay close attention, you'll know how to handle the Mennonites next week.

"If you want to look at the future of your denomination," I said, " you only have to look at how the Southern Baptists were transformed from criticizing evolution in the schools to promoting it. This was bound to happen, with all the preachers telling their people there's no evidence that primitive hominids ever existed.

${ }^{\alpha}$ That might have been fine in the day when, to check out that claim, a person would have had to sit down at a PC and hunt around for hours - who has time for that? But now for those who have PADs, questions like that get answered with just a few thoughts and a quick menu selection on their retinas. Presto - they're looking at a sequence of hominid photos with increasing cranial capacities over time. And seeing is believing, even if you've been home-schooled and never heard of evolution except as a naughty word. The result: anti-evolution leaders were voted out by an informed electorate.

"If our projections hold, $80 \%$ of American teens and adults are going to own a
PAD within three years. There's no choice about that, but what you can still choose, courtesy of our latest design and your specs, is whether your PAD will be your enemy or your friend.

"We've designed a friendly PAD. It's not just a matter of helping people make good decisions by showing them their best options - it actually does the rationalizing for them, too. This is as close to real human thinking as any PAD has ever come." going according to plan. The Presbyteri-

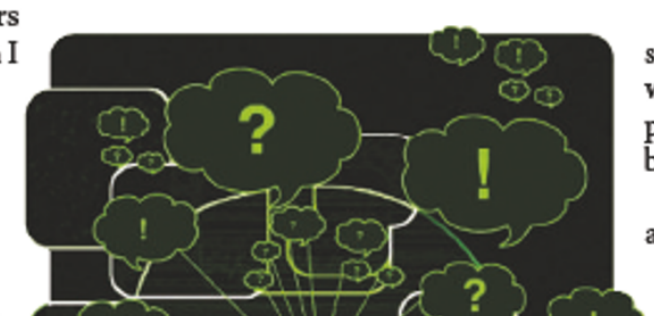

Now at this point, I thought we were still

logically dismissed it - and everyone knows a PAD's logic is flawless. It also showed an alternative, God-honouring explanation for the putative evidence. It suggested that several of the questions were based on false preconceptions. And always, it directed people to look at their denominational virtwebs, where they would get the true picture. Of course, we restricted access to the problem virtwebs.

"So," I concluded, "it really operates exactly as the human mind does. It chooses what it wants to believe."

That's when the biologist piped up and said something about our spoiling the $\succsim$ whole point of genuine choice: young people shouldn't be made to choose between faith and science.

"Of course not," his leaders said. "Not as long as you're talking about Christian science."

${ }^{\alpha}$ We're seeing the Christian Science people next week," said James. And from there things got very confusing.

The Presbyterian biologist got into an in-house discussion with his leaders about whether the particular means God used to create our bodies should be the issue.

"It certainly is the issue," the Presbyterian president said.

"It shouldn't be," said the biologist, "because the more genetics or history our bodies share with other animals, the greater the wonder at what we humans uniquely experience: morality, humour, literature, science, faith."

"Dr Adams," said the president, "you ans had brought their biologist to give me the chance to demonstrate how our PAD works. I let him fire away with his toughest questions.

${ }^{\alpha}$ How do you explain the stark differences between animals across impassible barriers, as between Australia and other lands? Why do islands always have organisms most like the nearest mainland? Why do we find clear evidence of common ancestry when we compare the DNA of an evolutionary sequence of animals, so that we can trace how genetic insertions, including retroviruses, appear and then accumulate in later forms oflife?"

The Adventists were set up for PADs and got answers in their heads. I showed the others on the large virtweb display what our PAD does compared with the others. As soon as any question was seen to contradict a specified tenet, our PAD were invited here to ask your questions and you've done that."

"But I have more," said Adams. "Do we really want to credit all these attributes merely to something special about our bodies, as if the material world is all there is? Isn't that what we're doing when we emphasize the special way our bodies were made? Isn't that what we're doing when we pit God against evolution?"

Some of the denominational leaders began to show a hint of worry. Fortunately, his remarks had triggered their PADs, which were already fast at work drowning him out with a flood of dazzling answers, backed up by well-documented evidence and memorable sound bites.

Fredric Heeren is a researcher and science writer in Kansas. By the time he finishes his book on human evolution, he fears we may have evolved into something else. 